\title{
Correction: Changes in Soil Microbial Community Structure Influenced by Agricultural Management Practices in a Mediterranean Agro-Ecosystem
}

\author{
Fuensanta García-Orenes, Alicia Morugán-Coronado, Raul Zornoza, Artemi Cerdà, \\ Kate Scow
}

Dr. Artemi Cerdà should be included in the author byline instead of the Acknowledgements. He should be listed as the fourth author, and his affiliation is: 5 SEDER (Soil Erosion and Degradation Research Group), Department of Geography, Universitat de València, Blasco Ibañez, 28, 46010, València, Spain. The contributions of this author are as follows: Conceived and designed the experiments: AC.

The correct citation is: García-Orenes F, Morugán-Coronado A, Zornoza R, Cerdà A, Scow K (2013) Changes in Soil Microbial Community Structure Influenced by Agricultural Management Practices in a Mediterranean Agro-Ecosystem. PLoS ONE 8(11): e80522. doi:10.1371/ journal.pone.0080522

\section{Reference}

1. García-Orenes F, Morugán-Coronado A, Zornoza R, Scow K (2013) Changes in Soil Microbial Community Structure Influenced by Agricultural Management Practices in a Mediterranean Agro-Ecosystem. PLoS ONE 8(11): e80522. doi: 10.1371/journal.pone.0080522 PMID: 24260409

G OPENACCESS

Citation: García-Orenes F, Morugán-Coronado A, Zornoza R, Cerdà A, Scow K (2016) Correction: Changes in Soil Microbial Community Structure Influenced by Agricultural Management Practices in a Mediterranean Agro-Ecosystem. PLoS ONE 11(3): e0152958. doi:10.1371/journal.pone.0152958

Published: March 31, 2016

Copyright: @ 2016 García-Orenes et al. This is an open access article distributed under the terms of the Creative Commons Attribution License, which permits unrestricted use, distribution, and reproduction in any medium, provided the original author and source are credited. 